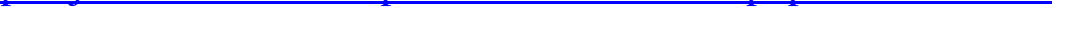

\title{
Pelatihan Pemamfaatan botol bekas untuk media pembelajaran di PAUD Tambusai
}

\section{Putri Hana Pebriana ${ }^{1}$}

Universitas Pahlawan Tuanku Tambusai, Riau, Indonesia ${ }^{1}$

e-mail : putripebriana99@gmail.com ${ }^{1}$

\begin{abstract}
Abstrak
Kegiatan Pengabdian Kepada Masyarakat ini bertujuan untuk 1) memberi pelatihan membuat benda fungsional dari bahan limbah botol plastik, 2) mengetahui respon guru di PAUD Pahlawan terhadap pelatihan pembuatan benda fungsional dari bahan limbah plastik. Pembuatan benda fungsional dari bahan limbah botol plastik sekaligus meningkatkan keterampilan dan kreativitas guru dalam memanfaatkan botol bekas sebagai media pengajaran.Metode kegiatan pengabdian masyarakat ini menggunakan metode ceramah,demontrasi, metode tanya jawab dan pelatihan membuat kreasi benda fungsional berupa tempat pencil, celengan, dan bunga.
\end{abstract}

Kata Kunci: Pemanfaatan Botol Bekas, Media Pengajaran

\begin{abstract}
This Community Service activity aims to 1) provide training to make functional objects from plastic bottles, 2) find a response teacher at PAUD Tambusai to training to make functional objects from plastic waste materials. Making functional objects from plastic waste materials increases the skills and creativity of teachers in utilizing used bottles as a supported medium. This method of community service uses lecture, demonstration, question and answer methods and training to create creative objects with pencil, piggy bank, and flowers.
\end{abstract}

Keywords: Utilization of Used Bottles, Teaching Media

Copyright (c) 2020 Putri Hana Pebriana

$\triangle$ Corresponding author:

Address : Alamat penulis

ISSN 2721-9224 (Media Cetak)

Email : Email Penulis

ISSN 2721- 9216 (Media Online)

Phone : Nomor HP 


\section{PENDAHULUAN}

Salah satu prasarat untuk mewujudkan masyarakat yang adil dan sejahtera adalah lebih ditentukan oleh sejauh mana kuwalitas sumber daya masyarakatnya. Kwalitas suatu bangsa sangat di tentukan oleh peran serta mutu pendidikan yang di pergunakan oleh bangsa tersebut. Masyarakat yang berperadaban adalah masyarakat yang berpendidikan. pendidikan adalah, suatu usaha sadar dalam rangka menanamkan daya-daya kemampuan, baik yang berhubungan dengan pengalaman kognitif (daya pengetahuan), affektif ( aspek sikap) maupun psikomotorik (aspek ketrampilan) yang dimiliki oleh seorang individu.

Namun dalam menjalankan pendidikan banyak sekali masalah atau kendala yang di temui atau di hadapi. Masalah dapat terjadi karena ada factor yang mempengaruhinya. Salah satu faktor yang mempengaruhi berjalan secara maksimal atau tidak proses pembelajaran adalah kecakapan guru dalam memilih model, pendekatan ataupun teknik pembelajaran yang tepat.

Seorang guru dalam perencanaan proses pembelajaran diharuskan memiliki pengetahuan serta kemampuan dalam memilih dan menentukan pendekatan pembelajaran yang tepat untuk digunakan. Dalam proses kegiatan pembelajaran di PAUD Tambusai guru dituntut untuk menggunakan media pembelajaran dalam proses pembelajaran sehingga guru harus kreatif menggunakan media pembelajaran. Memanfaatkan barang bekas seperti botol bekas dapat dibuat menjadi media pembelajaran di PAUD Tambusai. Berkaitan dengan hal ini, hal yang terjadi di PAUD Tambusai dalam proses pembelajaran salah satu permasalahan yang terjadi adalah guru kurang terampil dalam memanfaatkan media dan sumber ajar sehingga tujuan pembelajaran tidak dapat tercapai secara optimal. Sehingga anak cepat merasa bosan dan tidak tertarik dalam mengikuti kegiatan di PAUD Tambusai. Keinginan sekolah/guru untuk meningkatkan kualitas sumber daya manusia sangat tinggi, namun terkendala oleh banyak faktor, seperti sulitnya untuk melaksanakan pelatihan dikarenakan pendanaan, kesempatan mengikuti pelatihan. Kurang bervariasi dalam menggunakan memanfaatkan barang bekas untuk media pembelajaran.

\section{METODE}

a. Mekanisme Pelaksanaan Kegiatan. Mekanisme pelaksanaan kegiatan secara umum berupa perencanaan/ persiapan, pelaksanaan, observasi dan evaluasi, serta refleksi.

b. Perencanaan. Kegiatan perencanaan yaitu sebagai berikut:

1. melakukan koordinasi dengan Kepala Sekolah sebagai pemberian izin pelaksanaan Pelatihan Pemanfaatan Botol Bekas untuk Media Pembelajaran di PAUD Tambusai

2. Melakukan penyusunan materi pelatihan pemanfaatan botol bekas untuk media pembelajaran.

c. Pelaksanaan

1. Menjelaskan mengenai pengertian dan pentingnya pemanfaatan botol bekas untuk media pembelajaran di PAUD Tambusai.

2. Pembuatan botol bekas untuk media pembelajaran di PAUD Tambusai

d. Observasi dan Evaluasi. Kegiatan observasi dilakukan secara langsung oleh tim pelaksana. Observasi berupa 
pengecekan hasil dari pembuatan botol bekas untuk media pembelajaran di PAUD Tambusai. Proses evaluasi dilaksanakan untuk mengetahui kekurangan dan kendala dalam pelaksanaan kegiatan pengabdian. Observasi dilakukan terhadap botol bekas untuk media pembelajaran di PAUD Tambusai oleh para guru mitra. Evaluasi dilakukan terhadap kualitas dan kreativitas produk yang dihasilkan.

e. Refleksi. Refleksi dilakukan bersama antara tim dan peserta (guru mitra). Hal ini dilakukan untuk mengetahui bagaimana proses pelaksanaan kegiatan. Refleksi dilakukan terhadap kegiatan yang telah dilaksanakan. Hal ini dilakukan semata-mata untuk mengetahui kekurangan-kekurangan atau kelebihan-kelebihan terhadap kegiatan-kegiatan yang telah dilakukan dalam rangka menetapkan rekomendasi terhadap keberlangsungan atau pengembangan kegiatan-kegiatan berikutnya. Hasil refleksi adalah perlu dilakukan suatu upaya untuk membantu meningkatkan

keterampilan dan kreativitas guru mitra

\section{HASIL DAN PEMBAHASAN}

Kegiatan pelatihan pembuatan media pembelajaran dari barang bekas diikuti oleh guru PAUD Tambusai. Secara umum kegiatan pelatihan pembuatan media pembelajaran sains ini berjalan lancar. Setelah kegiatan workshop ini diharapkan peserta menggunakan barang bekas untuk media sains dan menggunakan media tersebut di sekolah masing-masing. Gambaran hasil pelatihan pada setiap tahapan dapat disampaikan sebagai berikut. 1) Koordinasi dengan pihak terkait Tim pengabdian melakukan koordinasi pihak terkait yaitu koordinator guru PAUD Tambusai dan mengurus perizinan pelaksanaan kegiatan pengabdian. Koordinasi dengan tim pengabdian yaitu dosen dan mahasiswa untuk mempersiapkan materi dan alat-alat yang digunakan dalam kegiatan pelatihan. 2) Pelaksanaan Pelatihan Kegiatan pelatihan dilaksanakan selama 4 hari (jadwal terlampir), bertempat di PAUD Tambusai Materi pelatihan disampaikan oleh tim pengabdian dengan materi pembelajaran sains di PAUD yang tepat

Kegiatan dimulai dengan dilakukan pre test untuk mengetahui kemampuan peserta. tentang materi pelatihan yang akan disampaikan. Kemudian dilanjutkan penyampaian materi oleh tim pengabdian tentang model dan media yang tepat dalam pembelajaran sains. Hari ke-2 peserta mendapat tugas untuk mengidentifikasi materi sains yang ada di PAUD secara berkelompok. Hari ke-3 peserta membuat media sains dari bahan bekas dengan bimbingan tim pengabdian baik dosen maupun mahasiswa. Di hari ke-4 peserta melakukan simulasi pembelajaran dengan menggunakan media sains dari barang bekas yang telah dibuat pada hari sebelumnya. Pelatihan diakhiri dengan dilakukan post test untuk mengetahui peningkatan pengetahuan tentang media pembelajaran sains setelah mendapatkan pelatihan.

Pelatihan pembuatan media sains dari barang bekas ini yang dilakukan selama 4 hari dan terdiri dari berbagai sesi diikuti dengan antusiasme peserta pelatihan. Guru sangat tertarik dengan materi yang disampaikan oleh tim pengabdian dan guru berpartisipasi aktif dalam setiap kegiatan pelatihan dengan bertanya kepada pemateri tentang materi yang kurang dipahami. Peningkatan wawasan tentang media pembelajaran juga 
mengalami peningkatan ditunjukkan dengan peningkatan nilai rata-rata pre test $57 \%$ dan nilai rata-rata post test $67 \%$. Produk yang dihasilkan berupa media sains yang terbuat dari barang bekas meliputi Berdasarkan angket, respon tentang pelatihan ini peserta menyatakan pelatihan sejenis dapat dilakukan kembali secara berkala, media bukan hanya media sains saja karena guru PAUD Tambusai merupakan guru kelas, selain itu media yang dibuat tidak hanya dari barang bekas tetapi media yang lebih variatif lagi. Pelaksanaan pelatihan pembuatan media pembelajaran sais terdapat faktor pendukung dan penghambat untuk mencapai hasil yang optimal.

\section{SIMPULAN}

Kegiatan Pengabdian Kepada Masyarakat ini bertujuan untuk 1) memberi pelatihan membuat benda fungsional dari bahan limbah botol plastik, 2) mengetahui respon guru di PAUD Pahlawan terhadap pelatihan pembuatan benda fungsional dari bahan limbah plastik. Pembuatan benda fungsional dari bahan limbah botol plastik sekaligus meningkatkan keterampilan dan kreativitas guru dalam memanfaatkan botol bekas sebagai media pengajaran. Metode kegiatan pengabdian masyarakat ini menggunakan metode ceramah,demontrasi, metode tanya jawab dan pelatihan membuat kreasi benda fungsional berupa tempat pencil, celengan, dan bunga.

\section{DAFTAR PUSTAKA}

Fathurrohman, P. \& Sutikno, S. 2009. Strategi Belajar Mengajar. Bandung: Refika Aditama.

Mulyasa, 2002. Kurikulum Berbasis Kompetensi. Bandung: PT Remaja Rosdakarya.

Sutarno, Nono, dkk, 2005. Materi dan Pembelajaran IPA SD. Jakarta: Universitas Terbuka .

Trianto, 2010. Model Pembelajaran Terpadu.Jakarta: Bumi Aksara. 